\title{
Reading Difficulties in English Language that Facing the Ninth Graders and How to Deal with these Difficulties from the Point of View of Teachers in Jordan
}

\author{
إعldats \\ راية عدنان الهواجدة - د.أحهد عيشم الحطويشيى \\ Doi: 10.12816/jacc.2020.123861

 \\ r.r./V/YO : الاستلام
}

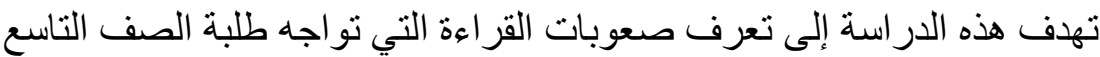

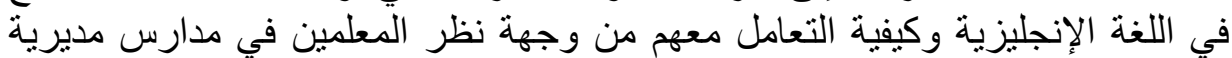

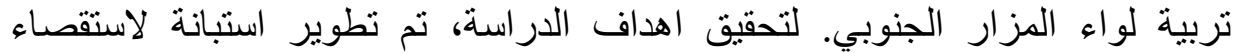

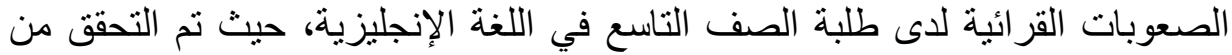

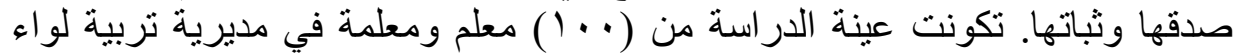

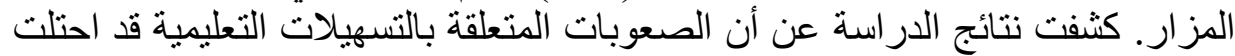



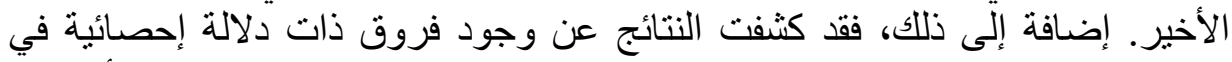



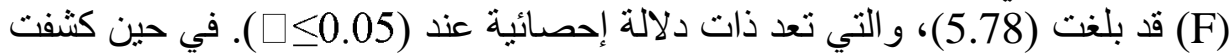

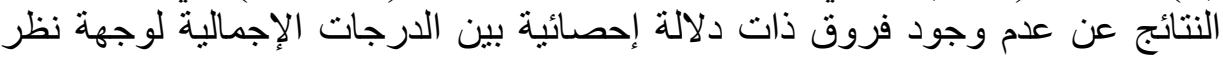



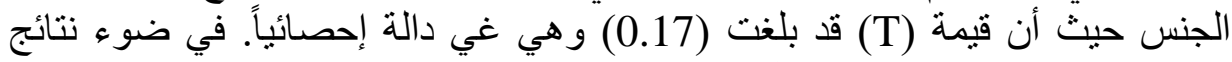

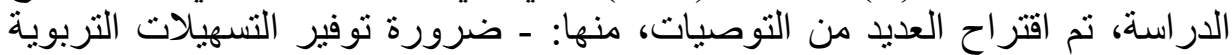

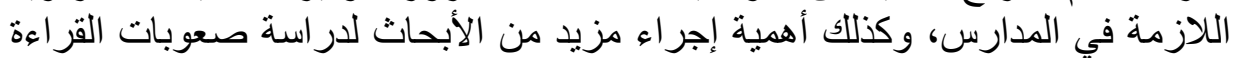


Abstract:

الكلمات المفتاحية: صعوبات القر ائية، القراءة، طلبة الطبة الصف التاسع الأساسي

This study aimed to identify the reading difficulties that facing the ninth graders in English language and how to deal with these difficulties from the point of view of teachers in Jordan. To achieve the study obective(s), a self-completed questionaire was 
developed to where its validity and reliabilty were verified. The sample of the study was comprised (100) teachers in Almazar Directorate of Education. The findings revealed that the difficulties related to teaching facilities and aids occupied the first rank with mean score of (3.97), whereas the domain of difficulties related to the domain of textbook occupied the last rank with total mean score of (3.13). Moreover, the study's findings indicated statistically significant differences on the teachers' perceptions, and these differences are attributed to the variable of years of experience, where the $(\mathrm{F})$ value reached (5.78). However, results indicated no statistically significant differences between the total scores of the English teachers' perceptions which attributed to the variable of gender where $(T)$ value reached 0.17 . In light of the results of the study, several recommendations were suggested, among which were: - Further research should be conducted to study the reading difficulties in English from students and their parents' perspective in addition to the necessity of providing schools with the required teaching facilities.

Keywords: Reading Difficulties, Reading, Ninth grade students

\subsection{Introduction}

In all communities all over the world, education is viewed as an operation of development, alteration and remedy of cultural and social thought, where the main use of language is to transfer these thoughts from generation to another. Thus, human societies are distinguished from others by language in which language is beholding as a connation system among individuals and sustenance social cohesion.

Therefore, in Jordan, educational system pay attention to teaching students several languages with special focus on the Arabic language as well as English language, which has recently attracted attention as it is the language of today's time and knowledge, and 
being as the language of era and science, in addition, it is believed that creativity is increased with the study of foreign language.

Reading, as one of the four skills of language learning, in general, and in English language in particular, it is a mixed implementation of an intellectual process and it forms a language method deem as one of the most notable and important language systems with other language skills such as listening, speaking and writing and individual rely on this system to gain language use within the classroom and in life (Ruddell, 1992).

Reading is an educational process in which the skills of word admission and understanding are alternately supportive. In the reading action, learners are expected to realize and comprehend what they read mostly in a paragraph. Without comprehending the text, students can't realize the implicit mission in a paragraph. (Duffy, 1988: 5)

According to Nunan (2003: 68), "reading is a well-spoken process of students join information from the text and their own background knowledge to build meaning".

Reading difficulty, as reported by Commeyrars and Inyega (2007), is a kind of learner's disability to read, where learners are usually read less safely than predicted despite the presence of natural intellect. Although the problem differs from person to person, the alternate feature of learners with difficulty in reading is difficulty in spelling, vocal processing, or verbal-visual reply. Furthermore, reading difficulty is a tender and difficult case to characterize. This is true since there are no two statuses which are properly alike so that they do form a divide up group in the pedagogical prospect. Supporting that, Al-Khuli (2000) reported that not all students who cannot read perfectly are disable students, only some of them are. On the other hand, some of the students who seem good in reading well, represent in fact a reading difficulty case. 
To sum up, reading difficulties need to be identified so the remedy course of corrective action(s) will be more easy to be proposed. Hence, this study came to investigate the reading difficulties that Ninth graders are facing, and how these difficulties can be tackled and resolved on light of some variables as perceived by the English language teachers in the schools of Southern Almazar Directorate of Education in Jordan.

Statement of the Problem

Reviewing the previous literature, it was claimed that many Arab students who learn English suffer from reading and find it difficult. In Jordan, as reported by Al Jamal \& Garaibeh (2016), students seem to perform poorly in reading skills which need to be improved. This is due to the many problems associated with learning foreign languages as a second language such as: - misuse tone, grammar and punctuation marks,... etc. In order to contribute in treating these problems and how to deal with them, the researcher focused on reading difficulties that are faced by Ninth graders as perceived by English teachers in the schools of Southern Almazar Directorate of Education in Jordan, in addition some solutions and suggestions to tackle the identified difficulties were suggested for future to overcome reading difficulties.

This study in particular investigated the reading difficulties that Ninth graders are facing as perceived by their teachers, and how these difficulties can be tackled and resolved.

Significance of the Study

The importance of this study is related to its capacity in helping teachers to identify the difficulties in reading in English language, and in sharing and adopting the proposed solutions and remedies, which might encourage teachers to adopt a new method to overcome the reading difficulties.

Questions of the Study

This study is devoted to answer the following questions; 
1- What are the reading difficulties that the $9^{\text {th }}$ graders encountering as perceived by English language teachers in Southern Almazar Directorate of Education in Jordan?

2- What are the proposed solutions to tackle the reading difficulties in English Language as perceived by the teachers in Southern Almazar Directorate of Education in Jordan?

3- Are there any statistically significant differences in identifying the reading difficulties as perceived by English language teachers in Southern Almazar Directorate of Education due to the variables of: gender (female and male) and years of experience (less than 5 years, 5-10 years and above 10 years)?

4- Are there any statistically significant differences in identifying the proposed solutions for reading difficulties that 9 th graders faced as perceived by English language teachers in Southern Almazar Directorate of Education due to the variables of: gender (female and male) and experience (less than 5 years, 510 years and above 10 years)?

Operational Definition of Terms

The terms of the study were operationally defined as follows:

- Reading: It is defined as the ability of $9^{\text {th }}$ graders to read English text from their own textbook.

- Reading difficulties: it is defined as the total score of the participants' estimations on the scale developed for the purposes of this study that included the following domains: difficulties related to English Language textbook; difficulties related to teaching facilities; difficulties related to teaching methods and difficulties related to students themselves.

- Ninth Graders: -They are those students who are about (15) years old at the Jordanian schools, and in particular at the schools of Southern Almazar Directorate of Education and have been receiving instruction in English language for 9 years now. 
Southern Almazar Directorate of Education: - It is one of the directorates of education, under the authority of the Ministry of education, located in south of Jordan within the Southern Al-mazar district.

Theoretical Framework

Learning a new language is very important in human life; the interest in learning a language is different from acquiring the mother tongue that contributes to the acquisition of new language skills, as well as a range of other skills, such as educational skills. In particular, English is taught as a foreign language or as a second language in schools. The teaching and learning of English language has significantly contributed to the allocation of international English language courses to all learning levels, and English language which is divided into skills that include the reading skill with which learners face many difficulties and problems, especially the ninth grade stage, which is considered the stage before the end of the completion of the basic education stage and the initiation of the secondary level.

According to (Action Pack 9), teaching reading provides many opportunities for students to read, understand and respond to written English in authentic informational and literary contexts. Learners also use reading strategies to demonstrate understanding of a variety of simple authentic material and make connections between prior knowledge and experiences and simple authentic material. According to the $\operatorname{MoE}(2014: 11)$ the end of this grade, students are expected to be able to:

- Make a list of words that are the same in Arabic and English and share it with peers to build vocabulary;

- build vocabulary by visiting a website with a "word of the day" feature;

- read silently different types of reading material for specific purposes; and 
- skim written materials before reading to determine their purpose or the type of the material. (Ministry of Education, 2014:11).

Definition of Reading

Reading, as defined by Manis, Lindsey, and Bailey, (2004:41), is "an individual's overall inter-relevance with symbolical input of the pupil thinking as interactive with the surroundings, taking in input, combine it, using it. The pupil is converting the information, organizing, re-organize and makes cohesion.

Within the same context, Smith, (2004) reaffirmed that reading is one of the most essential educational skills, and reported that in the advanced world, it is mostly viewed as a major skill desired for gaining. However, unfortunately, there are many children with reading difficulties. Where learning to read is one of the most depressing things students may face, and at most, the barriers they face hinder their desires to read, and without the suitable instruction, they will never overcome these barriers.

Definition of Reading Difficulties

Reading difficulties vary from an age stage to another. When underage difficulties happen and are not familiar and immediately corrected, their mischievous effects become accumulative and this leads to an intense difficulty. (Hosp and Reschly, 2003).

Reading difficulty has many characteristics that include difficulties in single words reading, primary difficulties in decoding or resonant out words, difficulties regarding reading visible words, meager phonological transition, reading full sentences, words of 5 syllables and syllables are included of personage sounds or voice, significance or receptive language difficulties and difficulties with understanding the themes. The processing difficulties may also be discovered in spelling and 
writing. Written expression lack and mathematics difficulty are commonly based in a string with a reading difficulty (Paris, 2005).

According to Jordanian experience, the general guidelines and general and specific outcomes for the English language curriculum of the $9^{\text {th }}$ grade, reading skill is to understand and respond to written English in a variety of simple authentic informational and literary contexts which is divided into two parts one is the general guideline and the other is the specific guideline as follows (as it appeared on the MoE, (2014): -

General guideline

It is expected that students will: -

1. Use reading strategies to understand a variety of simple authentic informational and literary reading materials.

2. Demonstrate understanding of a variety of simple authentic informational and literary reading material (e.g., biographies, narratives, and poems).

3. Make connections between prior knowledge and experiences and a variety of simple authentic informational and literary reading material (e.g., biographies, narratives, and poems, etc.).

Specific Outcomes

It is expected that students will;

1- Make a list of words that are the same in Arabic and English and share it with peers to build vocabulary, by visiting a website with a "word of the day" feature.

2- Read silently different types of reading materials for specific purposes (e.g., library resources for information; poems for enjoyment)

3- Skim written materials before reading to determine their purpose or the type of the material

4- Scan reading materials for general information for a project. 
5- Use print and electronic dictionaries and glossaries to confirm word meanings, pronunciation, parts of speech, derivations, and clarify shades of meaning.

6- Identify the relationship among facts, ideas, concepts and themes in reading Materials and analyze text content to develop a supported interpretation.

7- Evaluate information in a variety of resources to select materials for personal or school-related purposes and interpret literary reading materials by asking and answering questions.

8- Explain connections between what they read, personal ideas and beliefs and read different types of magazine and newspaper articles to obtain information and show enjoyment.

Bearing in mind these expected outcomes, it can be claimed that if the teacher or the learners facing any difficulties in achieving these outcomes then they will turn into difficulties instead of objectives to be achieved.

Factors that Cause Difficulty in Reading:

Pigada and Schmitt (2006) reported that there are many educational factors that cause reading difficulty, which might and often do take part as parts of a congregation pattern of causes. Where one factor may be comparatively considered more important than others, among these are the following:

1- Teachers-Related Factors:

Generally speaking, it is expected that teacher's personality in particular, when having negative perspectives towards specific group of students may lead to complicate the difficulty. Thus, Bell (2001) pointed out that teachers of English can encourage reading through affirmative impact by inspiring an appropriate mood in each classroom. Positive teachers are authentic, contending to help their students and always do their best for them. Maggi (2004) indicated that the function of the English teacher himself is to act 
as a substantial program as he/she can have an affirmative or negative effect on forward in teaching reading. Learners /students are actually lucky if their English teachers are so masterful, welltrained and well-disposed. This preserves good students -English teacher's relationships and is worthy to achieve a suitable equation in improving skills and capability in the reading program.

2- Students-Related Factors:

Catts and Hogan (2003) asserted that reading was viewed as things achieved with one's eyes, having said that, a deficit in visible perception, is the master factor that causes difficulty in reading. In particular, where the repeated decision reflection mistakes in poor readers have reinforced a visual-based explication of reading difficulties. Thus, it is necessary to focuses on the influence of teaching method on the language skills of students. Within this context, Gay (2011) indicated that a reading difficulties might have related to the student(s)'s environment which in turn prevents him/her from obtaining learning capacity and this difficulty may exist at any stage of school beginning from the 1st class until the higher school levels.

3- Textbook-Related Factors:

Khankar $(200 r)$ presents that teachers have to give pupils the chance to pursue the skill of reading out of diverse activities and not to be restricted with textbook only. That means being restricted to the textbooks could be sometimes another source for reading difficulty that student encountering.

4- Teaching Methods-Related Factors:

Ojanen (2007) indicates that reading difficulty can be as a reflection of employing unsuitable teaching methods. Teachers have a lot of action in teaching literacy skills so that a lot of children would turn to be well-spoken readers. Relevant to the teaching method is to what extent the teacher is efficient in using the appropriate classroom environment, for instance factors related 
to the school environment with special reference to the availability of educational facilities that makes the task of teacher and the learner as well, easy, because the lack of the appropriate learning environment and the lack of educational facilities may hinder tear teacher from using the proper teaching method.

Suggested Remedies for Reading Difficulties:

Many studies on the language foundation of reading difficulties have a proposition for remediation so that students with reading difficulty can benefit from remediation directed across the language problems that underlie reading inability.

According to Erica (2018), There are several domains for remedies, among which are those teachers-related, student-related, textbook-related and teaching methods-related remedies, these domains are more explained as following:

Teachers-Related Remedies for reading difficulties:

This domain could include several suggestions such as;

1- Teachers mustn't take off points when students display reflection

2- Color symbol popular reflection to help students understand diversities, for example, make the letter $b$ blue and the letter $\mathrm{d}$, red, and so on.

Students-Related Remedies for reading difficulties:

This domain could include several suggestions such as;

1- Promoting students to either read along or imagine the story.

2- Supporting students to read along when listening can get better chase, whole word confession.

Textbook-Related Remedies for Reading Difficulties:

This domain could include several suggestions such as;

1- Supplying technological audio version of the text.

2- Displaying a big font with lesser content on every page.

3- Supply verbal directions, checking for perception and renewing directions when necessary.

4- Expanding directions and highlighting keywords. 
Teaching Methods-Related Remedies for Reading Difficulties:

This domain could include several suggestions such as;

1- Performing cheerfulness activities that reinforce participation capacity from the reflex group.

2- Extending strategies: For example, transitioning the highest and least signs.

\subsection{Literature Review}

Many researchers have addressed the topic of reading difficulties in English language, therefore the researcher was able to review several studies that addressed the topic, below are some of these reviewed related early studies.

The study of Yassen (2013) examines the reading difficulties in English language and how to deal with them among the $10^{\text {th }}$ graders in Nablus district as perceived by teachers of English. Results indicated that reading difficulties faced by student in learning English language were due to students' reading behaviors, in addition, context teaching aids and teaching methods had a significant effect on reading difficulties. The researcher recommended with holding training courses for teachers to provide them with the sufficient experience to appropriately teach their students the reading skill.

The study of Mwanamuk (2013) investigates the factors that contribute to causes of reading difficulties among grade six learners and the challenges faced by teachers in teaching them how to read. The study results inducated that most of the grade six students were not able to read fluently as expected compared their grade level. Results revealed that teachers faced a number of challenges in teaching reading to these learners. These challenges included, inadequate teaching and learning materials, high teacher - pupil ratio and others. Based on these findings, the study recommended that apart from just providing adequate learning and teaching materials and building, more schools and remedial 
measures on reading difficulties must be taught to teachers so that they are adequately prepared to help learners with reading difficulties.

The study of Mule (2014). identifies the causes of reading difficulties affecting reading English among Grade four (4) learners in the Ogongo circuit in Namibia. Results indicated that inadequate English reading materials, improper teaching methodology and insufficient English language development were causes of reading difficulties in the circuit. The research recommended that schools should making available the financial resources to provide with supplementary reading materials for learners, and that teachers should encourage learners to borrow books from libraries to practice reading independently and teachers should study English through the English Language Proficiency Program run jointly by the Ministry of Education and the University of Namibia.

The study of Novi (2015) investigates reading difficulties of young learners learning English as a foreign language (EFL) in formal school settings in Serbia. The results showed that there was a statistically significant difference in reading difficulties in relation to both individual and contextual factors, and that reading difficulties in early EFL reading may have been the result of adverse effects of some individual and contextual factors, like poor linguistic and strategic competences of young learners, negative transfer of L1 literacy, inappropriate teaching approach, and insufficient exposure to L2 texts. Taxonomy of reading difficulties was complied, comprising $25 \mathrm{~L} 2$ reading difficulties. These results have significant implications for designing EFL reading and prevention programs, for teaching beginning reading, and for preservice and in-service EFL teacher education and training.

The study of Albdour (2015) identifies the difficulties affecting the student in the area of reading comprehension skill in English language curricula. Results indicated a high score on the 
difficulties' scale indicating that seventh grade students faced high problems and difficulties in reading comprehension skill of English language curricula. The highest averages were in the area of problems and difficulties that reduce the efficiency of comprehension process with a mean of (4.00) and a standard deviation of (0.57), while the lowest means where in the area of reading comprehension skills with a mean of (3.66) and a standard deviation of (0.65). Results indicated no statistically significant differences between participants' responses that could be attributed to gender. The study suggested several recommendations such as: providing schools with linguistic laboratories that allow students to practically apply English as it's the language of communication and contact; and encouraging students to use English as a means of communication among each other and between them and their teachers instead of excessive use of Arabic language.

The study of Nurjanah, (2018) investigates the difficulties faced by students, in Indonesia, in practicing reading comprehension to find the perfect technique or method to overcome the problem. The method of this study was an explanatory multi-method strategy by applying a pretest on students then the results of the vocabulary knowledge or mastery were analyzed. These problems were related to the poor habit of reading and the less interesting reading comprehension course they had in the classroom. Students needed more interactive learning activities to be applied in the classroom such as games, or audio visual media to keep them interested in the lecture or reduce the anxiety. It was recommended that teachers should be more aware of the problems faced by students and provide with more interactive teaching techniques.

Conclusion

The researchers concluded that most of previous studies which addressed the reading difficulties in English language and how to 
deal with them, were mostly focusing on learners with sometimes a rare combination of the learners and teachers view. Thus, and for the researchers' best knowledge, none of the previous studies investigated reading difficulties with a focus on teacher's perceptions. More interestingly, the uniqueness of the current study is germane to the reality that it is the first within its context that have been carried out on the schools of the directorate of education of Almazar, thus it is expected to contribute to the knowledge and the educational literature about the area of Almazar in Jordan.

Methodology of the study

The study followed the analytic descriptive method, and this method was utilized due to the nature of the study and its appropriateness to achieve its objectives.

The population of the study

According to the statistics of the Directorate of Education of the Southern AL Mazar during the second semester 2018/2019, the population of the study comprised (194) $9^{\text {th }}$ Grade-English teachers (69 male and 125 female teachers).

The sample of the study

The basic representative sample of the study was assigned to at approximately $50.0 \%$ of the population of the study, thus the intention was to reach the sample of (100) $9^{\text {th }}$ Grade-English teachers (60 female and 40 male teachers). However, since the researcher was able to collect data from only (99) teachers, the final sample was consisted of (99) participants as shown in Table (1).

Table (1): The distribution of the study sample according to the variables of

Gender and years of teaching experience

\begin{tabular}{|c|c|c|c|}
\hline Variables & Categories & Numbers & Percentages \% \\
\hline \multirow{3}{*}{ Gender } & Male & 40 & 40.40 \\
\cline { 2 - 4 } & Female & 59 & 59.60 \\
\hline
\end{tabular}


Doi: 10.12816/jacc.2020.123861

راية المواجلة - د.أحمل الطويسي

\begin{tabular}{|c|c|c|c|}
\hline & Total & 99 & 100 \\
\hline \multirow{3}{*}{$\begin{array}{c}\text { Years of } \\
\text { experiences }\end{array}$} & Less than 5 years & 27 & 27.28 \\
\cline { 2 - 4 } & From 5-10 years & 46 & 46.46 \\
\cline { 2 - 4 } & More than 10 years & 26 & 26 \\
\cline { 2 - 4 } & Total & 99 & 100 \\
\hline
\end{tabular}

Instrument of the study

A questionnaire was developed as the major instrument in order to achieve the objectives of this study. Initially, the researcher developed a 42-items questionnaire to identify the reading difficulties that face the ninth grade students, however, the final draft was consisted of (39) items distributed over (4) domains. Then, and depending on the results of the first questionnaire, the researcher developed a second questionnaire to seek teachers' suggestions about the proposed remedies for reading difficulties. In this regard the outputs of the first questionnaire was a channel for constructing the second questionnaire. More clearly, the items with high mean scores were considered as the core of suggested remedies, thus the second questionnaire was consisted of (11) items distributed on (3) domains related to administrative issue, curriculum and teacher.

The responses to both questionnaires were based on the strongly agree, agree, uncertain, disagree and, strongly disagree scale (as the teacher is concerned with teaching method and teaching facilities).

Table (2) shows the distribution of the domains and the items within both questionnaires.

Table (2): Domains and items of the questionnaires of reading difficulties and the questionnaire of the proposed remedies of reading difficulties 
Reading difficulties domains

Items

Textbook-Related difficulties

$1-11$

Teaching-Facilities Related difficulties

$12-17$

Teaching Method Related difficulties

$18-25$

Students-Related difficulties

$26-39$

Domains of proposed remedies

\section{Items}

Curriculum-Related

8Administrative -Related

$1-3$

Teacher-Related

$4-$

$9-11$

Validity and reliability of the instrument

A- Validity

The validity of the initial version of the study instrument (questionnaire) was verified by presenting it to a jury of (12) arbitrators of experienced specialists including the faculty members in Jordanian universities, a group of experienced educational supervisors and English language teachers who teach English language for $9^{\text {th }}$ graders, in addition to a group of experienced specialists in assessment and evaluation. They were asked to review the items (included in the questionnaire) and to check the linguistics appropriateness and items' relevance to the purpose of the study. They were asked to modify, delete or add items as they deem appropriate. Based on their opinions, some alterations were addressed, such as some items were modified while some others were deleted.

B- Construct Validity

To verify the construct validity of the study instrument, it was applied on a pilot sample of (30) male and female teachers 
from the study population but outside its original sample. Table (3), shows the Pearson

Table (3): The Correlation coefficients of items of the difficulties questionnaire with the total score and the Domain to which they belong

\begin{tabular}{|c|c|c|c|c|c|c|c|}
\hline \multicolumn{2}{|c|}{$\begin{array}{c}\text { Textbook- Related } \\
\text { Difficulties }\end{array}$} & \multicolumn{2}{c|}{$\begin{array}{c}\text { Teaching Facilities- } \\
\text { Related Difficulties }\end{array}$} & $\begin{array}{c}\text { Teaching Methods- } \\
\text { Related } \\
\text { Difficulties }\end{array}$ & \multicolumn{2}{c|}{$\begin{array}{c}\text { Students-Related } \\
\text { Difficulties }\end{array}$} \\
\hline $\begin{array}{c}\text { Item } \\
\text { No }\end{array}$ & $\begin{array}{c}\text { correlation } \\
\text { coefficients }\end{array}$ & $\begin{array}{c}\text { Item } \\
\text { No }\end{array}$ & $\begin{array}{c}\text { correlation } \\
\text { coefficients }\end{array}$ & $\begin{array}{c}\text { Item } \\
\text { No }\end{array}$ & $\begin{array}{c}\text { correlation } \\
\text { coefficients }\end{array}$ & $\begin{array}{c}\text { Item } \\
\text { No }\end{array}$ & $\begin{array}{c}\text { correlation } \\
\text { coefficients }\end{array}$ \\
\hline 1 & $* * 0.48$ & 12 & $* * 0.39$ & 18 & $* * 0.48$ & 26 & $* * 0.38$ \\
\hline 2 & $* * 0.35$ & 13 & $* * 0.37$ & 19 & $* * 0.40$ & 27 & $* * 0.44$ \\
\hline 3 & $* * 0.37$ & 14 & $* * 0.45$ & 20 & $* * 0.51$ & 28 & $* * 0.56$ \\
\hline 4 & $* * 0.35$ & 15 & $* * 0.56$ & 21 & $* * 0.52$ & 29 & $* * 0.45$ \\
\hline 5 & $* * 0.40$ & 16 & $* * 0.45$ & 22 & $* * 0.54$ & 30 & $* * 0.33$ \\
\hline 6 & $* * 0.42$ & 17 & $* * 0.51$ & 23 & $* * 0.55$ & 31 & $* * 0.48$ \\
\hline 7 & $* * 0.44$ & - & - & 24 & $* * 0.57$ & 32 & $* * 0.43$ \\
\hline 8 & $* * 0.33$ & - & - & 25 & $* * 0.45$ & 33 & $* * 0.39$ \\
\hline 9 & $* * 0.4$ & - & - & - & - & 34 & $* * 0.41$ \\
\hline 10 & $* * 0.60$ & - & - & - & - & 35 & $* * 0.45$ \\
\hline 11 & $* * .46$ & - & - & - & - & 36 & $* * 0.37$ \\
\hline- & - & - & - & - & - & 37 & $* * 0.39$ \\
\hline- & - & - & - & - & - & 38 & $* * 0.40$ \\
\hline- & - & - & - & - & - & 39 & $* * 0.44$ \\
\hline
\end{tabular}

* significant at $(\alpha \leq 0.01)$

Correlation coefficients of items on each domain level and at the level of the overall instrument.

It is clear from the results in Table (3) that the correlation coefficients for the scores of the items of the study instruments ranged between $(0.33$ and 0.60$)$ and these values indicate that tool is appropriate for the purposes it was developed for.

Reliability 
Reliability of the study instrument was determined by calculating the Cronbach Alpha coefficient, and based on the results of applying the instrument on the pilot sample, the reliability coefficient for each domain and the instrument as whole are shown in the Table (4).

Table (4): Cronbach Alpha coefficient for each of the difficulties' domains and the questionnaire as whole

\begin{tabular}{|c|c|c|}
\hline Domain & Items' & Cronbach Alpha \\
\hline Textbook & 11 & 0.89 \\
\hline Teaching Facilities and Aids & 6 & 0.87 \\
\hline Teaching Methods & 8 & 0.89 \\
\hline difficulties related to the students & 14 & 0.88 \\
\hline The instrument as whole & 39 & 0.91 \\
\hline
\end{tabular}

Reviewing the results in table (4), the study instrument had high level of reliability, where the overall reliability coefficient of the instrument was 0.91 and the reliability coefficient values for the study instrument domains ranged from 0.87 to 0.89 .

Correction Criteria

As reference for classifying the responses of the participants the following criteria was adopted:

The mean scores of 2.33 or less reflects low level of reading difficulties and thus no urgent remedies are required.

The mean scores of more than 2.33 and less than 3.67 reflects moderate level of reading difficulties and such these difficulties are in need of slight remedies.

The mean scores of 3.67 and above reflects high level of reading difficulties and thus urgent remedies are required.

Results and Discussion

The present study was an attempt to investigate the reading difficulties that the ninth graders are encountering in English Language and how to treat these difficulties as perceived by their teachers. In this chapter the results of the (the answers of the 
research questions) were presented and discussed according to the aforementioned aims and sub aims (study objectives) as follows:

Firstly: Results related to the research first question: -

What are the reading difficulties that the $9^{\text {th }}$ graders encounter as perceived by English language teachers?

To answer the first question of the study, Mean scores and standard deviations for the perceptions of the teachers were analysed and presented as shown in the Table (5).

Table (5): Mean scores and standard deviations for the domains of the reading difficulties faced by ninth graders as perceived by their teachers

\begin{tabular}{|c|c|c|c|c|c|}
\hline No & domains & Mean & $\begin{array}{c}\text { Std. } \\
\text { Deviation }\end{array}$ & Rank & level \\
\hline 1 & Textbook- Related Difficulties & 3.133 & 0.98 & 4 & moderate \\
\hline 2 & $\begin{array}{c}\text { Teaching Facilities and Aids- } \\
\text { Related Difficulties . }\end{array}$ & 3.974 & 1.01 & 1 & high \\
\hline 3 & $\begin{array}{c}\text { Teaching Methods-Related } \\
\text { Difficulties }\end{array}$ & 3.347 & 1.12 & 2 & moderate \\
\hline 4 & Students-Related Difficulties & 3.150 & 1.04 & 3 & moderate \\
\hline- & Total & 3.401 & $\cdot .85$ & - & moderate \\
\hline
\end{tabular}

The results in Table (5) shows that the overall level of reading difficulties faced by ninth graders was at the moderate level of difficulty with an overall mean score of (3.40), and a standard deviation of (0.85). The difficulties related to teaching facilities occupied the first rank with the a mean of (3.97) at a high level of reading difficulty, second rank was occupied by the domain of reading difficulties related to teaching methods with a mean of (3.34), at a moderate level of reading difficulty, then the domain of difficulties related to students at the third rank with a mean of (3.15) at a moderate level of reading difficulty, and finally came the domain of the difficulties related to the textbook occupied the 
fourth rank with a mean of (3.133), at a moderate level of reading difficulty.

The results of the items (sub- difficulties) within each domain of the study instrument are presented as follows:

1- The first domain: Textbook-Related reading difficulties faced by ninth graders:

The Mean scores and the standard deviations of each reading difficulty item within this domain were calculated and presented as shown in the Table (6).

The results presented in Table (6) above show that the mean scores of the difficulties related to the domain of the textbook were ranged between 2.77

and 4.03. It is worth noting that item (1) "Textbook does not make connection between text and students' prior knowledge", is the only

Table (6): Mean scores and standard deviations of reading difficulties faced by ninth graders related to the domain of the textbook

\begin{tabular}{|c|c|c|c|c|c|}
\hline No & Items & Mean & S.D & Rank & $\begin{array}{c}\text { Level of } \\
\text { reading } \\
\text { difficulty }\end{array}$ \\
\hline 1 & $\begin{array}{c}\text { Textbook does not make } \\
\text { connection between text and } \\
\text { students' prior knowledge. }\end{array}$ & 4.030 & 0.96 & 1 & High \\
\hline 7 & $\begin{array}{c}\text { Textbook activities does not allow } \\
\text { students to perform oral } \\
\text { presentations. }\end{array}$ & 3.313 & 1.07 & 2 & Moderate \\
\hline 3 & $\begin{array}{c}\text { Exercises included in the textbook } \\
\text { do not encourage students to read. }\end{array}$ & 3.242 & 1.2 & 3 & Moderate \\
\hline 2 & $\begin{array}{c}\text { The textbook contains } \\
\text { unattractive comprehension } \\
\text { passages. }\end{array}$ & 3.152 & 0.8 & 4 & Moderate \\
\hline
\end{tabular}


Doi: 10.12816/jacc.2020.123861

راية المواجلة - د. - د

\begin{tabular}{|c|c|c|c|c|c|}
\hline 10 & $\begin{array}{c}\text { The textbook does not have } \\
\text { enough pictures that help in } \\
\text { explaining the meaning of new } \\
\text { vocabularies. }\end{array}$ & 3.111 & 1.05 & 5 & Moderate \\
\hline 4 & $\begin{array}{c}\text { Activities included in the textbook } \\
\text { do not encourage students to use } \\
\text { dictionaries. }\end{array}$ & 3.030 & 1.01 & 6 & Moderate \\
\hline 8 & $\begin{array}{c}\text { The textbook has inappropriate } \\
\text { exercise about reading. }\end{array}$ & 3.020 & 1.08 & 7 & Moderate \\
\hline 11 & $\begin{array}{c}\text { Articles and stories are boring and } \\
\text { not interesting to encourage } \\
\text { students practicing reading skill. }\end{array}$ & 3.010 & 1.17 & 8 & Moderate \\
\hline 5 & $\begin{array}{c}\text { Textbook does not provide texts } \\
\text { that could be used in real life } \\
\text { situations. }\end{array}$ & 2.980 & 1.12 & 9 & Moderate \\
\hline 5 & $\begin{array}{c}\text { The textbook contains some } \\
\text { difficult words }\end{array}$ & 2.798 & 1.04 & 10 & Moderate \\
\hline & $\begin{array}{c}\text { Textbook does not encompasses } \\
\text { strategies that facilitate teacher's } \\
\text { task to evaluate students in } \\
\text { reading skill effectively. }\end{array}$ & 2.778 & 1.03 & 11 & Moderate \\
\hline & Total & 3.133 & 0.98 & - & Moderate \\
\hline
\end{tabular}

difficulty with high level of reading difficulty, while the rest of the items within the domain were at moderate level of reading difficulty.

Second domain: Teaching Facilities and Aids -Related Reading difficulties:

The mean scores and standard deviations for each item within the domain of reading difficulties related to teaching facilities was analyzed and presented as shown in Table (7). 
Table (7): Mean scores, standard deviations and the level of reading difficulties faced by the ninth graders related to the domain of Teaching Facilities

\begin{tabular}{|c|c|c|c|c|c|}
\hline No & items & Mean & Std. Deviation & Rank & level \\
\hline 12 & $\begin{array}{c}\text { School lack for English language } \\
\text { labs. }\end{array}$ & 4.18 & 1.00 & 1 & high \\
\hline 14 & $\begin{array}{c}\text { Schools lack for a rich language } \\
\text { environment to engage students in } \\
\text { small group speaking activities. }\end{array}$ & 4.14 & 1.11 & 2 & high \\
\hline 16 & $\begin{array}{c}\text { The lack for extracurricular activities } \\
\text { germane to reading skill in English } \\
\text { language. }\end{array}$ & 3.94 & 1.08 & 3 & high \\
\hline 13 & The lack of access to internet. & 3.91 & 1.04 & 4 & high \\
\hline 15 & $\begin{array}{c}\text { Shortage in the sufficiency of the } \\
\text { learning aids. }\end{array}$ & 3.87 & 1.16 & 5 & high \\
\hline 17 & $\begin{array}{c}\text { Inefficient utilization of the available } \\
\text { electronic technology. }\end{array}$ & 3.80 & 1.14 & 6 & high \\
\hline & Total & 3.97 & $1 . \cdot 1$ & - & high \\
\hline
\end{tabular}

The results presented in Table (7) reveal that the mean scores of the reading difficulties within this domain were ranged between 3.8 and 4.18. Moreover, it can be noticed that all the items in this domain gained high levels of reading difficulties as perceived by English language teachers.

Third domain: Teaching Methods -Related Reading difficulties faced by ninth graders:

The mean scores and standard deviations for each item within the domain of reading difficulties related to teaching methods was calculated and analyzed and presented as shown in table (8).

The results presented in Table (8) indicates that the overall mean score of the difficulties related to teaching methods was (3.35) and a standard deviation of (1.12), with overall moderate level of difficulty. Moreover, at the items level, item (18) stating that: Utilized teaching strategies are inadequate to provide opportunities for peer tutoring. 
As well as item (21) stating that: Utilized teaching/learning strategies does not provide choices, for reading assignments, were at high

Table (8): Mean and standard deviations of Reading difficulties faced by ninth graders related to the domain of Teaching Methods

\begin{tabular}{|c|c|c|c|c|c|}
\hline No & items & Mean & $\begin{array}{c}\text { Std. } \\
\text { Deviation }\end{array}$ & Rank & level \\
\hline 18 & $\begin{array}{l}\text { Utilized teaching strategies are adequate to } \\
\text { provide opportunities for peer tutoring. }\end{array}$ & 3.90 & 0.79 & 1 & high \\
\hline 21 & $\begin{array}{l}\text { Utilized teaching/learning strategies do not } \\
\text { provide choices for reading assignments. }\end{array}$ & 3.86 & 1.11 & 2 & high \\
\hline 23 & $\begin{array}{l}\text { Teaching strategies does not employ the } \\
\text { available electronic technology efficiently. }\end{array}$ & 3.49 & 0.94 & 3 & moderate \\
\hline 22 & $\begin{array}{l}\text { Teaching strategies, neglect the role of } \\
\text { extracurricular activities to enrich student's } \\
\text { reading skill in English language. }\end{array}$ & 3.46 & 0.71 & 4 & moderate \\
\hline 20 & $\begin{array}{l}\text { Utilized teaching approaches did not } \\
\text { encourage students to recite/rehearse } \\
\text { information }\end{array}$ & 3.21 & 0.95 & 5 & moderate \\
\hline 24 & $\begin{array}{l}\text { The document of teacher guide does not } \\
\text { provide teacher with a variety of teaching } \\
\text { strategies that suits teaching reading skill. }\end{array}$ & 3.14 & 0.80 & 6 & moderate \\
\hline 25 & $\begin{array}{l}\text { Teaching strategies does not encourage } \\
\text { students to use print or electronic } \\
\text { dictionaries to enhance the acquiring of } \\
\text { reading skill. }\end{array}$ & 2.96 & 0.88 & 7 & moderate \\
\hline 19 & $\begin{array}{l}\text { The absence of multi-sensory (auditory, } \\
\text { visual, and tactile) instructional approaches. }\end{array}$ & 2.77 & 1.14 & 8 & moderate \\
\hline & Total & 3.35 & $1.1 Y$ & - & moderate \\
\hline
\end{tabular}

levels of difficulty, with means of (3.90) and (3.86) respectively, while the rest of the items had means ranged between (2.77-3.49), with moderate level of difficulty.

The fourth domain: Students-related reading difficulties faced by the ninth graders: The means and standard deviations for each item within this domain were analyzed and presented as shown in Table (9). 
Table (9): Mean scores standard deviations and level of reading difficulties faced by the ninth graders related to the domain of the students

\begin{tabular}{|c|c|c|c|c|c|}
\hline No & Items & Mean & $\begin{array}{l}\text { Std. } \\
\text { Deviati } \\
\text { on }\end{array}$ & Rank & level \\
\hline 26 & $\begin{array}{c}\text { Make a list of words that are the same in Arabic } \\
\text { and English and share it with peers to build } \\
\text { vocabulary. }\end{array}$ & 3.83 & 1.01 & 1 & high \\
\hline 28 & $\begin{array}{l}\text { Read silently different types of reading materials } \\
\text { for specific purposes (e.g. library resources for } \\
\text { information; poems for enjoyment). }\end{array}$ & 3.79 & 1.08 & 2 & high \\
\hline 35 & $\begin{array}{l}\text { Interpret literary reading materials by asking and } \\
\text { answering questions. }\end{array}$ & 3.21 & 1.18 & 3 & moderate \\
\hline 37 & $\begin{array}{c}\text { Explain connections between what they read, } \\
\text { personal ideas and beliefs. }\end{array}$ & 3.20 & 1.07 & 4 & moderate \\
\hline 36 & $\begin{array}{l}\text { Make connections between prior knowledge and } \\
\text { experiences and a variety of simple authentic } \\
\text { informational and literary reading material (e.g., } \\
\text { biographies, narratives, and poems, etc.). }\end{array}$ & 3.13 & 1.18 & 5 & moderate \\
\hline 31 & $\begin{array}{c}\text { Demonstrate understanding of a variety of } \\
\text { simple authentic informational and literary } \\
\text { reading material (e.g., biographies, narratives, } \\
\text { and poems). }\end{array}$ & 3.11 & 1.17 & 6 & moderate \\
\hline 32 & $\begin{array}{l}\text { Identify the relationship among facts, ideas, } \\
\text { concepts and themes in reading materials. }\end{array}$ & 3.10 & 1.19 & 7 & moderate \\
\hline 29 & $\begin{array}{l}\text { Skim written materials before reading to } \\
\text { determine their purpose or the type of the } \\
\text { material. }\end{array}$ & 3.06 & 1.20 & 8 & moderate \\
\hline 27 & $\begin{array}{l}\text { Build vocabulary by visiting a website with a } \\
\text { "word of the day" feature. }\end{array}$ & 3.05 & 0.97 & 9 & moderate \\
\hline 38 & $\begin{array}{l}\text { Read different types of magazine and newspaper } \\
\text { articles to obtain information and show } \\
\text { enjoyment. }\end{array}$ & 3.03 & 1.09 & 10 & moderate \\
\hline 33 & $\begin{array}{l}\text { Analyze text content to develop a supported } \\
\text { interpretation. }\end{array}$ & 3.02 & 1.05 & 11 & moderate \\
\hline 30 & $\begin{array}{l}\text { Use print and electronic dictionaries and } \\
\text { glossaries to confirm word meanings, } \\
\text { pronunciation. }\end{array}$ & 2.98 & 1.11 & 12 & moderate \\
\hline
\end{tabular}




\section{Doi: 10.12816/jacc.2020.123861}

\begin{tabular}{|c|c|c|c|c|c|}
\hline 34 & $\begin{array}{c}\text { Evaluate information in a variety of resources to } \\
\text { select materials for personal/school-related } \\
\text { purposes. }\end{array}$ & 2.96 & 1.04 & 13 & moderate \\
\hline 39 & $\begin{array}{c}\text { Read independently to acquire information on } \\
\text { topics related to hobbies and interests. }\end{array}$ & 2.87 & 1.21 & 14 & moderate \\
\hline & Total & 3.15 & 1.04 & - & moderate \\
\hline
\end{tabular}

The results indicated in Table (9) shows that the overall mean score of fourth domain of difficulties related to the students was (3.15) and a standard deviation of (1.04) with overall moderate level of difficulty. Moreover, it can be recognized that item (26), stating that: Make a list of words that are the same in Arabic and English and share it with peers to build vocabulary. and item (28) stating that; Read silently different types of reading materials for specific purposes (e.g. library resources for information; poems for enjoyment), both of them had high levels of difficulty with means of (3.84) and (3.69) respectively. However, the rest of items were with a moderate level of difficulty, with mean scores ranging from (2.89-3.21).

Discussions of the results related to the research first question revealed the following:

Results indicated that the general level of the reading difficulties faced by $9^{\text {th }}$ graders as perceived by English language teachers were generally estimated at medium level. The difficulties related to teaching facilities and aids occupied the first rank with high level of difficulty, followed by the difficulties related to teaching methods occupied the second ran. The difficulties related to textbook were at the third rank with a medium level of difficulty, and finally the difficulties related to the students occupied the fourth rank with a medium level of difficulty.

The high level of difficulties related to teaching facilities and aids could be attributed to the lack of the material and technical aids in public schools in Almazar Directorate of Education. These facilities which are expected to facilitate teachers' task in the use of methods for teaching the reading skill 
in English language which in turn needs advanced materials accessible at what is known as linguistics' lab provided with computer programs and software to teach reading skill and training students on it.

Although the Ministry of Education seeks to offer the modern and more advanced educational and teaching materials at computer labs in schools, there still a great lack for these materials in many schools in Almazar district, and on the other hand, it could be claimed, (as observed by the researchers), that there is a lack for the appropriate interest and concern among school administrations and some teachers toward the importance of using these materials and aids within classroom and activating its use by students.

With regard to the difficulties related to teaching methods in the many aspects, it can be reported that teachers are mostly avoid to use some teaching methods because they are ill-equipped to apply the new teaching methods which need more demanding planning and preparation by the teacher. In addition to the lack for sufficient time for teachers which may also hinder the application of new educational and teaching methods, in addition to the lack for the adequate training courses they attend in the field of new teaching methods application.

Regarding the difficulties related to textbook, the results interpreted the need for curriculum developers to pay more attention to reading skills and their applications within lessons. Moreover, curriculum developers are required to evaluate the connection between its content and the students' prior knowledge. Actually, the current used curriculum of English language may achieve its goals and objectives and may have effectiveness among ordinary students but they may have less effectiveness regarding developing the reading skill appropriate for less achievers.

With regard to the difficulties related to the students, results can be interpreted by the lack of teaching facilities and aids that facilitate students' task in practicing reading skill more easily and 
more confidently regardless whether reading is for information or for enjoyment.

In light of the aforementioned results germane to the reading difficulties faced by 9 th graders as seen by English language teachers in Southern Almazar Directorate of Education and compared to previous studies' results, it can be reported that despite the lack for such previous studies that directly addressed the topic of this study, the results here are in agreement with the results of some previous studies such as (Yassin ,2013) and ( Mule , 2014) which indicated a significant effect for teaching aids and teaching methods on reading difficulties.

Secondly: Results related to the research second question: What are the proposed solutions to tackle the reading difficulties in English Language as perceived by the teachers in Southern Almazar Directorate of Education?

To recognize the proposed solutions to tackle the reading difficulties faced by 9 th graders, means and standard deviations of teachers' perceptions were analyzed and presented as shown in table (10).

Table (10): Means and standard deviations for the teachers' perceptions toward the proposed remedies for reading difficulties of the ninth graders.

\begin{tabular}{|c|c|c|c|c|c|}
\hline No & Domain & Mean & S.D & Rank & level \\
\hline 1 & $\begin{array}{c}\text { Proposed Remedies Related to } \\
\text { Curriculum Domain }\end{array}$ & 3.492 & 0.97 & 1 & moderate \\
\hline 2 & $\begin{array}{c}\text { Proposed Remedies Related to } \\
\text { Administrative Domain } \\
\text { (at the levels of Ministry of Education } \\
\text { and Schools) }\end{array}$ & 3.151 & 0.87 & 3 & moderate \\
\hline $3 \quad \begin{array}{c}\text { Proposed Remedies Related to the } \\
\text { Domain of Teachers (including } \\
\text { teaching methods and availability of } \\
\text { teaching facilities) }\end{array}$ & 3.415 & 0.93 & 2 & moderate \\
\hline & \begin{tabular}{c} 
Total \\
\hline
\end{tabular} & 3.353 & 0.59 & - & moderate \\
\hline
\end{tabular}


The results shown in Table (10) reveal that the total level of proposed solutions to tackle the reading difficulties faced by 9 th graders has reached a moderate level of importance, with overall mean score of (3.35), and a standard deviation of (0.59).

However, at the domain level, the proposed solutions related to the curricula domain were ranked first with a Mean of (3.49) at a moderate level, where the second rank was occupied by the domain of proposed remedies related to the teachers (including teaching methods and availability of teaching facilities), with a Mean score of (3.41) at a moderate level of importance, and the third rank was occupied by the remedies related to the administrative domain (at the levels of the Ministry of Education and Schools) with a mean score of (3.15) at a moderate level.

Furthermore, at the level of each domain, the responses to the items within the domains of the proposed solutions are presented as follows:

First domain: Curriculum-Related Proposed Remedies:

Results presented in Table (11) indicate that the overall Mean was (3.49), and the standard deviation reached 0.97 for this domain. At the items level, item (1) stating that: "Curriculum should be designed in such a way to encourage learners to read various types of reading materials silently for specific purposes (e.g. library resources for information; poems for enjoyment". achieved the highest score of importance with a mean of Table (11): Mean scores and standard deviations for proposed remedies related to the domain of curriculum

\begin{tabular}{|c|c|c|c|c|c|}
\hline No & items & Mean & S.D & Rank & level \\
\hline 1 & $\begin{array}{c}\text { Curriculum should be designed in such a } \\
\text { way to encourage learners to read various } \\
\text { types of reading materials silently for } \\
\text { specific purposes (e.g. library resources for } \\
\text { information; poems for enjoyment). }\end{array}$ & 3.71 & 1.33 & 1 & high \\
\hline 3 & $\begin{array}{c}\text { The developers of English Language } \\
\text { curriculum are required to take, deeply, into }\end{array}$ & 3.70 & 1.23 & 2 & $\begin{array}{c}\text { moder } \\
\text { ate }\end{array}$ \\
\hline
\end{tabular}


Doi: 10.12816/jacc.2020.123861

\begin{tabular}{|c|c|c|c|c|c|}
\hline No & items & Mean & S.D & Rank & level \\
\hline & $\begin{array}{l}\text { consideration the connection between the } \\
\text { content of textbooks and students' prior } \\
\text { knowledge. }\end{array}$ & & & & \\
\hline 2 & $\begin{array}{l}\text { Curriculum developers are required to take } \\
\text { into account the importance of } \\
\text { encompassing the English Language } \\
\text { textbooks with a list of similar words in } \\
\text { Arabic and English for the purpose to build } \\
\text { and identify vocabulary. }\end{array}$ & 3.11 & 1.12 & 3 & $\begin{array}{c}\text { moder } \\
\text { ate }\end{array}$ \\
\hline & Total & 3.49 & $\cdot .97$ & - & $\begin{array}{c}\text { moder } \\
\text { ate }\end{array}$ \\
\hline
\end{tabular}

(3.71) and the rest of the items were classified at the moderate level means ranging between (3.11-3.70).

Second domain: Administrative -Related Proposed Remedies (at the levels of Ministry of Education and Schools).

Results presented in Table (12), indicate that the overall level of importance was at moderate a total mean of (3.15) and a standard deviation of (0.87). However, at items level, all items achieved moderate level of perceptions, and the Mean scores ranged between (2.55-3.55), where item (5) stating that "Ministry of Education should provide schools with proper Internet services" and item (7) stating that "Schools are required to establish a rich language learning environment to engage students in small group speaking activities" occupied the first rank with a mean score of (3.55 for each of them.

Table (12)

Means and standard deviations for proposed Remedies related to Administrative domain - (at the levels of Ministry of Education and Schools)

\begin{tabular}{|c|c|c|c|c|c|}
\hline No & items & Mean & S.D & Rank & level \\
\hline 5 & $\begin{array}{c}\text { Ministry of Education should provide } \\
\text { schools with proper Internet services. }\end{array}$ & 3.556 & 1.31 & 1 & moderate \\
\hline 7 & $\begin{array}{c}\text { Schools are required to establish a rich } \\
\text { language learning environment to }\end{array}$ & 3.554 & 1.46 & 2 & moderate \\
\hline
\end{tabular}




\begin{tabular}{|c|c|c|c|c|c|}
\hline No & items & Mean & S.D & Rank & level \\
\hline & $\begin{array}{l}\text { engage students in small group speaking } \\
\text { activities }\end{array}$ & & & & \\
\hline 6 & $\begin{array}{l}\text { Ministry of Education and schools are } \\
\text { required to increase teaching aids that } \\
\text { may facilitates teachers' endeavors in } \\
\text { the teaching and students task in the } \\
\text { learning. }\end{array}$ & 3.077 & 1.36 & 3 & moderate \\
\hline 4 & $\begin{array}{c}\text { Ministry of education should provide } \\
\text { schools with modernized appropriate } \\
\text { language labs. }\end{array}$ & 3.015 & 1.14 & 4 & moderate \\
\hline \multirow[t]{2}{*}{8} & $\begin{array}{l}\text { Schools are required to increasing the } \\
\text { extracurricular activities, in English } \\
\text { Language, and connecting them to } \\
\text { reading skills in English. }\end{array}$ & 2.554 & 1.35 & 5 & moderate \\
\hline & Total & 3.151 & $\cdot .87$ & - & moderate \\
\hline
\end{tabular}

Third domain: Teachers-Related Proposed Remedies:

Results presented in the Table (13), indicate that the overall level of importance was at moderate level with a total mean score of (3.41), and a standard deviation of (0.93), where at the items level, item (9) stating that:

Table (13)

Means and standard deviations for Teachers-Related Proposed Remedies

\begin{tabular}{|c|c|c|c|c|c|}
\hline No & items & Mean & S.D & Rank & level \\
\hline 9 & $\begin{array}{c}\text { Teachers are required to adopt the } \\
\text { learning strategies that provide the } \\
\text { opportunity for reading assignments. }\end{array}$ & 3.785 & 1.34 & 1 & high \\
\hline $\begin{array}{c}\text { Teachers should have to employ } \\
\text { teaching strategies that provide peer } \\
\text { learning. }\end{array}$ & 3.400 & 1.33 & 2 & moderate \\
\hline 10 & $\begin{array}{c}\text { Teachers are required to employ } \\
\text { effectively the available electronic } \\
\text { technology for purpose of English } \\
\text { Language teaching and learning. }\end{array}$ & 3.062 & 1.24 & 3 & moderate \\
\hline & Total \\
\hline
\end{tabular}


"Teachers are required to adopt the learning strategies that provide the opportunity for reading assignments". Occupied the first rank with a mean score of (3.78) at high level of importance, while the remainder of the items achieved moderate level of significance with means ranging between (3.06-3.40).

Discussion of the results related to the research second question:

It can be noticed that the general level of the importance of the suggested remedies/solutions to overcome reading difficulties faced by 9th graders was perceived at a medium level, and among the included remedies/solutions related to the curriculum domain was that curriculum should be designed in such a way to encourage learners to read various types of reading materials silently for a specific purposes (e.g. library resources for information; poems for enjoyment) and that the developers and designers of the English Language curriculum are required to take, deeply, into consideration the connection between the content of textbooks and students' prior knowledge.

For the proposed remedies related to the administrative domain at both levels of the Ministry and the schools, the most important among them were that the Ministry of Education should provide schools with proper Internet services and the schools are required to establish a rich language learning environment to engage students in small group speaking activities, which in turn, is expected to encourage students to more practice reading skill in various ways.

Regarding solutions proposed for remedies related to the domain of teachers, they include that teachers are required to adopt the learning strategies that provide the opportunity for reading assignments, in addition teachers are required to employ teaching strategies that provide opportunity for peer learning, which reflects the necessity of such learning method, thus it is expected that using 
of peer learning will lead to encourage students to learn from each other, and through direct interaction between learners will promotes active learning and allowing great understanding.

Thirdly: Results related to the research third question:

Are there any statistically significant differences at $(\alpha \leq 0.05)$ in determining the reading difficulties as perceived by English language teachers in Southern Almazar Directorate of Education based on the variables of: gender (female /male) and years of experience (less than 5 years, 5-10 years and more than 10 years)?

To answer this question, Means and standard deviation for teachers' perceptions were calculated and presented based on the variables of gender and years of experience, as following:

Gender Variable

Table (14) presents the results related to variable of gender, and in order to investigate if there were any statistically significant differences in

Table (14): T-test results for the differences between perceptions of participants' Means based on the variable of gender

\begin{tabular}{|c|c|c|c|c|c|c|c|}
\hline variable & sex & No & Mean & $\begin{array}{c}\text { Std. } \\
\text { Deviation }\end{array}$ & $\mathrm{df}$ & “t”' & Sig \\
\hline \multirow{2}{*}{$\begin{array}{c}\text { Textbook-Related } \\
\text { Difficulties }\end{array}$} & Male & 40 & 3.156 & 0.74 & \multirow{2}{*}{97} & \multirow{2}{*}{0.50} & \multirow{2}{*}{0.62} \\
\hline & Female & 59 & 3.108 & 0.71 & & & \\
\hline \multirow{2}{*}{$\begin{array}{c}\text { Teaching Facilities and } \\
\text { Aids - Related } \\
\text { Difficulties }\end{array}$} & Male & 40 & 3.949 & 0.80 & \multirow[b]{2}{*}{97} & \multirow[b]{2}{*}{0.86} & \multirow[b]{2}{*}{0.39} \\
\hline & Female & 59 & 4.058 & 0.96 & & & \\
\hline \multirow{2}{*}{$\begin{array}{l}\text { Teaching Methods - } \\
\text { Related Difficulties }\end{array}$} & Male & 40 & 3.334 & 0.64 & \multirow{2}{*}{97} & \multirow{2}{*}{0.33} & \multirow{2}{*}{0.74} \\
\hline & Female & 59 & 3.362 & 0.68 & & & \\
\hline \multirow{2}{*}{$\begin{array}{l}\text { Students-Related } \\
\text { Difficulties }\end{array}$} & Male & 40 & 3.214 & 0.51 & \multirow{2}{*}{97} & \multirow{2}{*}{1.99} & \multirow{2}{*}{0.06} \\
\hline & Female & 59 & 3.079 & 0.66 & & & \\
\hline \multirow{2}{*}{ Total } & Male & 40 & 3.413 & 0.61 & \multirow{2}{*}{97} & \multirow{2}{*}{0.17} & \multirow{2}{*}{0.86} \\
\hline & Female & 59 & 3.402 & 0.55 & & & \\
\hline
\end{tabular}


determining the reading difficulties as perceived by English language teachers based on the variable of gender. The (T) test for independent samples was employed.

Results shown in table (14) indicate no statistically significant differences that can be attributed to the variable of gender. The total calculated $(\mathrm{T})$ value was 0.17 , which is not statistically significant at $(\alpha \leq 0.05)$. Moreover, there were no statistically significant differences in participants' perceptions that are attributed to the

variable of gender at all domains of reading difficulties, where the (T) values ranged between (.79-1.99). More precisely, the (T) values were; $0.33,0.50,0.86$ and 1.99 , for the domains of teaching methods, textbook, teaching facilities and students, respectively.

The Variable of Years of Experience

Table (15) presents the results related to variable of years of experience, and in order to investigate if there were any statistically significant differences at $\alpha \leq 0.05$ in determining the reading difficulties, the Two way - ANOVA analysis was employed and the results of the variance in the participants' perceptions as shown in Table (15).

Table (15): Means and standard deviations of the differences between participants' estimation for the reading difficulties that faced the ninth graders based on the variable of years of teaching experience

\begin{tabular}{|c|c|c|c|c|}
\hline variable & Exp. & No & Mean & $\begin{array}{c}\text { Std. } \\
\text { Deviation }\end{array}$ \\
\hline \multirow{2}{*}{$\begin{array}{c}\text { Textbook-Related } \\
\text { Difficulties }\end{array}$} & Less than 5 & 27 & 2.891 & 0.47 \\
\cline { 2 - 5 } & $5-10$ & 46 & 3.134 & 0.54 \\
\cline { 2 - 5 } & More Than 10 & 26 & 3.374 & 0.46 \\
\hline \multirow{2}{*}{$\begin{array}{c}\text { Teaching Facilities and Aids } \\
\text {-Related Difficulties }\end{array}$} & Less than 5 & 27 & 3.752 & 0.54 \\
\cline { 2 - 5 } & $5-10$ & 46 & 3.955 & 0.69 \\
\cline { 2 - 5 } & More Than 10 & 26 & 4.331 & 0.61 \\
\hline Teaching Methods -Related & Less than 5 & 27 & 3.115 & 0.43 \\
\hline
\end{tabular}




\begin{tabular}{|c|c|c|c|c|}
\hline \multicolumn{2}{|c|}{ المجلد الثالث - العدد (rا ) أكتوبر •r.r. مـ } & \multicolumn{3}{|c|}{ المجلة العربية لإعلاهروثتافة الطفل } \\
\hline variable & Exp. & No & Mean & $\begin{array}{c}\text { Std. } \\
\text { Deviation }\end{array}$ \\
\hline \multirow[t]{2}{*}{ Difficulties } & $5-10$ & 46 & 3.375 & 0.38 \\
\hline & More Than 10 & 26 & 3.609 & 0.42 \\
\hline \multirow{3}{*}{ Student-Related Difficulties } & Less than 5 & 27 & 2.908 & 0.28 \\
\hline & $5-10$ & 46 & 3.152 & 0.41 \\
\hline & More Than 10 & 26 & 3.497 & 0.55 \\
\hline \multirow{3}{*}{ Total } & Less than 5 & 27 & 3.144 & 0.32 \\
\hline & $5-10$ & 46 & 3.404 & 0.36 \\
\hline & More Than 10 & 26 & 3.681 & 0.48 \\
\hline
\end{tabular}

Reviewing the results in table (15), it can be noticed that there were apparent differences in the level of participants' estimations that are attributed to the variable of years of experience.

In order to investigate whether these differences are statistically significant, the One Way ANOVA was performed, and the results are presented in table (16).

Overall results in table (16) indicate statistically significant differences at $(\alpha \leq 0.05)$ that are attributed to the variable of years of experience, where the calculated $(\mathrm{F})$ value reached (5.78), which is

Table (16): One way - ANOVA analysis' results for the variance in the perceptions based on the variable of years of experience

\begin{tabular}{|c|c|c|c|c|c|c|}
\hline variable & Source & $\begin{array}{l}\text { Sum of } \\
\text { Squares }\end{array}$ & d.f & $\begin{array}{l}\text { Mean } \\
\text { Square }\end{array}$ & $\mathrm{F}$ & \\
\hline \multirow{3}{*}{$\begin{array}{l}\text { Textbook-Related } \\
\text { Difficulties }\end{array}$} & Between Groups & 2.09 & 2 & 1.05 & \multirow{3}{*}{$4.60 *$} & \multirow{3}{*}{0.00} \\
\hline & Within Groups & 21.85 & 96 & 0.23 & & \\
\hline & Total & 23.94 & 98 & - & & \\
\hline \multirow{3}{*}{$\begin{array}{l}\text { Teaching Facilities } \\
\text { and Aids - Related } \\
\text { Difficulties }\end{array}$} & Between Groups & 4.00 & 2 & 2.00 & \multirow{3}{*}{$5.04 *$} & \multirow{3}{*}{0.00} \\
\hline & Within Groups & 38.02 & 96 & 0.40 & & \\
\hline & Total & 42.02 & 98 & - & & \\
\hline \multirow{2}{*}{$\begin{array}{l}\text { Teaching Methods - } \\
\text { Related Difficulties }\end{array}$} & Between Groups & 2.36 & 2 & 1.18 & \multirow{2}{*}{$7.11^{*}$} & \multirow{2}{*}{0.00} \\
\hline & Within Groups & 15.94 & 96 & 0.17 & & \\
\hline
\end{tabular}


Doi: 10.12816/jacc.2020.123861

راية المواجلة - د.أحمل الطويسي

\begin{tabular}{|c|c|c|c|c|c|c|}
\hline & Total & 18.30 & 98 & & & \\
\hline \multirow{3}{*}{$\begin{array}{c}\text { Student-Related } \\
\text { Difficulties }\end{array}$} & Between Groups & 2.24 & 2 & 1.12 & \multirow{3}{*}{$9.54 *$} & \multirow{3}{*}{0.00} \\
\cline { 2 - 6 } & Within Groups & 11.28 & 96 & 0.12 & \multirow{3}{*}{$5.78^{*}$} & \multirow{3}{*}{0.00} \\
\cline { 2 - 6 } & Total & 13.53 & 98 & & \\
\hline \multirow{3}{*}{ Total } & Between Groups & 1.25 & 2 & 0.62 & \\
\cline { 2 - 5 } & Within Groups & 10.38 & 96 & 0.11 & \\
\cline { 2 - 5 } & Total & 11.62 & 98 & & & \\
\hline
\end{tabular}

* significant at $\alpha \leq 0.05$ level

statistically significant at $(\alpha \leq 0.05)$, In addition, and at the level of domains results indicate that there were statistical significant differences at $(\alpha \leq 0.05)$ at the levels of all domains, where the values of $(\mathrm{F})$ calculated reached $(4.60,5.04,7.11$, and 9.59) respectively for the domains of (textbook, teaching facilities, teaching methods and students' related difficulties), in particularly regarding the variables of years of experience.

To determine the sources of differences between Mean scores, the Scheffe Post Hock Comparisons Test was performed, and the results are shown in the Table (17). Results in Table (17) reporting the followings:

Table (17): The Scheffe' Test for Post Hoc Comparisons for the differences that could be attributed to the variable of years of experience

\begin{tabular}{|c|c|c|c|c|c|}
\hline \multirow{2}{*}{ variable } & \multirow{2}{*}{ Exp. } & \multirow[t]{2}{*}{ Mean } & $\begin{array}{l}\text { Less } \\
\text { than } 5\end{array}$ & $1 \cdot-0$ & $\begin{array}{c}\text { More Than } \\
10\end{array}$ \\
\hline & & & \multicolumn{3}{|c|}{ Mean Difference } \\
\hline \multirow{3}{*}{$\begin{array}{c}\text { Difficulties } \\
\text { related to } \\
\text { Textbook }\end{array}$} & Less than 5 & 2.891 & - & -0.243 & $-0.483^{*}$ \\
\hline & $1 \cdot-0$ & 3.134 & - & -0.240 & - \\
\hline & More Than 10 & 3.374 & - & - & - \\
\hline \multirow{3}{*}{$\begin{array}{c}\text { Difficulties } \\
\text { related to } \\
\text { Teaching } \\
\text { Facilities }\end{array}$} & Less than 5 & 3.752 & - & -0.047 & $-0.479 *$ \\
\hline & $1 \cdot-0$ & 3.799 & - & $-0.432 *$ & \\
\hline & More Than 10 & 4.231 & - & - & - \\
\hline \multirow{2}{*}{$\begin{array}{l}\text { Difficulties } \\
\text { related to }\end{array}$} & Less than 5 & 3.115 & - & -0.260 & $-0.494 *$ \\
\hline & $1 \cdot-0$ & 3.375 & - & - & - \\
\hline
\end{tabular}




\begin{tabular}{|c|c|c|c|c|c|}
\hline \multicolumn{3}{|c|}{ المجلد الثالث - العدد (r) أكتوبر +r.rم } & \multicolumn{3}{|c|}{ المجلة العربية لإعلاهروثقافة الطفل } \\
\hline \multirow[t]{2}{*}{ variable } & \multirow[t]{2}{*}{ Exp. } & \multirow[t]{2}{*}{ Mean } & $\begin{array}{l}\text { Less } \\
\text { than } 5 \\
\end{array}$ & $1 \cdot-0$ & $\begin{array}{c}\text { More Than } \\
10 \\
\end{array}$ \\
\hline & & & \multicolumn{3}{|c|}{ Mean Difference } \\
\hline $\begin{array}{l}\text { Teaching } \\
\text { Methods }\end{array}$ & More Than 10 & 3.609 & - & - & - \\
\hline \multirow{3}{*}{$\begin{array}{l}\text { Difficulties } \\
\text { related to the } \\
\text { students }\end{array}$} & Less than 5 & 2.908 & - & -0.244 & $-0.589 *$ \\
\hline & $1 \cdot-0$ & 3.152 & - & -0.345 & - \\
\hline & More Than 10 & 3.497 & - & - & - \\
\hline \multirow{3}{*}{ Overall } & Less than 5 & 3.144 & - & -0.260 & $-0.537 *$ \\
\hline & $1 \cdot-0$ & 3.404 & - & -0.277 & - \\
\hline & More Than 10 & 3.681 & - & - & - \\
\hline
\end{tabular}

* significant at the 0.05 level

Overall, there were statistically significant differences at $\alpha \leq 0.05$ between the mean scores of perceptions, and these differences are attributed to the variable of years of experience and were in favor of the experience category (more than 10 years) with a total mean of (3.68), and the highest difference between mean scores reached (0.537), which is a statistically significance at $(\alpha \leq 0.05)$.

Moreover, at the domains level, results revealed that there were statistically significant differences at $\alpha \leq 0.05$ between the mean scores of English language teachers' perceptions related to all domains related to the variable of years of experience, on favor of the years of experience category (more than 10 years), where the mean scores for the domains of: textbooks, teaching facilities, teaching methods and student related difficulty, respectively, reached $(3.37,4.23,3.6$ and 3.49).

Discussions of the results related to the research third question, it was indicated that there were no significant statistical differences between the total score for English language teachers' perceptions regarding the reading difficulties faced by $9^{\text {th }}$ graders based on the variable of gender. In addition, there were no significant statistical differences between the total score for English language teachers' 
perceptions regarding the reading difficulties faced by $9^{\text {th }}$ grade students in relation to the aspects of difficulties at all domains.

These results could be explained by that the teachers' prior knowledge backgrounds reflects their agreement on the difficulties faced by students in reading, in addition to the similarity of educational and teaching environment in both male and female schools, which in turn explain these results. Supporting that, these results are in agreement with those of (Albdour, 2015), in particular, where it was revealed that there were significant statistical differences could be attributed to the variable of years of experience, in favor of teachers with long experiences (more than 10 years). The explanations of these results could be attributed to that teachers with long experiences in teaching English language are more familiar about the difficulties faced by students in reading skills, in addition they are more familiar about the nature of teaching the reading skill and more capable in identifying the required educational and teaching materials and methods.

Fourthly: - Results related to the research fourth question: Are there any statistically significant differences at $\alpha \leq 0.05$ in identifying the proposed solutions for reading difficulties that $9^{\text {th }}$ graders faced as perceived by English language teachers in Southern Almazar Directorate of Education due to the variables of: gender (female and male) and experience (less than 5 years, 5-10 years and above 10 years)?

To answer the fourth research question, analytical statistical tests were conducted to investigate the difference in the level of English language teacher's perceptions towards proposed solutions to tackle the English reading difficulties facing the ninth-grade students that could be attributed to the gender variable, where the (t-test) was used for independent samples, the results are shown in table (18) below: 
Table (18): T-Test results for the differences between English teacher's perceptions towards the proposed solutions to tackle the difficulties of reading in English language facing the ninth graders that is attributed to variable of gender.

\begin{tabular}{|c|c|c|c|c|c|c|c|}
\hline Variable & Gender & No & Mean & $\begin{array}{c}\text { Std. } \\
\text { Deviation }\end{array}$ & df & "T" & Sig \\
\hline \multirow{2}{*}{$\begin{array}{l}\text { Curriculum -Related } \\
\text { Proposed Remedies }\end{array}$} & Male & 40 & 3.509 & 0.80 & \multirow{2}{*}{97} & \multirow{2}{*}{0.87} & \multirow{2}{*}{0.45} \\
\hline & female & 59 & 3.475 & 0.77 & & & \\
\hline \multirow{2}{*}{$\begin{array}{l}\text { Administrative Domain- } \\
\text { Related Proposed } \\
\text { Remedies (at the levels of } \\
\text { Ministry of Education and } \\
\text { Schools) }\end{array}$} & Male & 40 & 3.0954 & 0.84 & \multirow[b]{2}{*}{97} & \multirow[b]{2}{*}{$\cdot, 60$} & \multirow[b]{2}{*}{$\cdot, 81$} \\
\hline & female & 59 & 3.204 & 1.01 & & & \\
\hline \multirow{2}{*}{$\begin{array}{c}\text { Teachers-Related } \\
\text { Proposed Remedies } \\
\text { (including teaching } \\
\text { facilities and teaching } \\
\text { methods) } \\
\end{array}$} & Male & 40 & 3.331 & 0.68 & \multirow[b]{2}{*}{97} & \multirow[b]{2}{*}{0.94} & \multirow[b]{2}{*}{$\cdot, 25$} \\
\hline & female & 59 & 3.359 & 0.71 & & & \\
\hline \multirow[t]{2}{*}{ Total } & Male & 40 & 3.341 & 0.64 & \multirow[t]{2}{*}{97} & \multirow[t]{2}{*}{1.06} & \multirow[t]{2}{*}{0.12} \\
\hline & female & 59 & 3.360 & 0.58 & & & \\
\hline
\end{tabular}

Results in Table (18) show that:

There were no statistically significant differences at $\alpha \leq 0.05$ between the total score of English language teachers perceptions towards the proposed solutions to tackle the difficulties of reading in English language that facing the ninth grades students that could be attributed to the variables of gender where the total (T) value reached (1.06), and this differences value is not statistically significant at level $(\alpha \leq 0.05)$.

Furthermore, and at the domains' levels, results confirm that there were no statistically significant differences at $\alpha \leq 0.05$ in the perceptions of English language teachers towards proposed remedies related to any of the domains of (curriculum, administrative and teacher related remedies) where their (T) values 
are respectively reached $(0.87,0.60$ and 0.94$)$, which are not statistically significant at the level $(\alpha \leq 0.05)$.

With regard to the variable of years of experience, the results as presented in table (19) shows that there were apparent differences at among teachers' perceptions towards the proposed solutions to tackle the reading

Table (19): Mean scores and standard deviations of the participants' perceptions towards proposed solutions to overcome English reading difficulties faced by ninth-graders that is attributed to the variables of years of experience.

\begin{tabular}{|c|c|c|c|c|}
\hline Variable & Exp. & No & Mean & $\begin{array}{c}\text { Std. } \\
\text { Deviation }\end{array}$ \\
\hline \multirow{2}{*}{$\begin{array}{c}\text { Curriculum-Related Proposed } \\
\text { Remedies }\end{array}$} & Less than 5 & 27 & 3.411 & 0.50 \\
\cline { 2 - 5 } & $5-10$ & 46 & 3.535 & 0.58 \\
\cline { 2 - 5 } & More Than 10 & 26 & 3.577 & 0.51 \\
\hline Total & & 99 & 3.49 & 0.97 \\
\hline $\begin{array}{c}\text { Administrative Domain } \\
\text {-Related Proposed Remedies } \\
\text { (at the levels of Ministry of } \\
\text { Education and Schools) }\end{array}$ & Less than 5 & 27 & 3.173 & 0.59 \\
\cline { 2 - 5 } & $5-10$ & 46 & 3.060 & 0.76 \\
\hline \multirow{2}{*}{$\begin{array}{c}\text { Teachers-Related Proposed } \\
\text { Remedies }\end{array}$} & More Than 10 & 26 & 3.218 & 0.67 \\
\cline { 2 - 5 } & Less than 5 & 27 & 3.351 & 0.47 \\
\cline { 2 - 5 } & More Than 10 & 26 & 3.506 & 0.46 \\
\hline Total & Less than 5 & 27 & 3.313 & 0.45 \\
\hline \multirow{2}{*}{ Totally } & $5-10$ & 46 & 3.346 & 0.41 \\
\hline Overall & More Than 10 & 26 & 3.402 & 0.52 \\
\hline & & 99 & 3.35 & 0.59 \\
\hline
\end{tabular}

difficulties. Hence, further analysis was conducted to investigate whether these differences are statistically significant. Therefore, One-way ANOVA was employed.

The results in table (20) show that: 
Overall, there were no statistically significant differences at $\alpha \leq 0.05$ among the perceptions of English language teachers that could be attributed to the variable of years of experience, where the value (F) reached (1.44), which is not statistically significant at the level $(\alpha \leq 0.05)$.

Table (20): One Way Anova Analysis Results for the variable in the perceptions toward the proposed solutions of the English language teachers according to the variable of years of experience.

\begin{tabular}{|c|c|c|c|c|c|c|}
\hline variable & Source & $\begin{array}{l}\text { Sum of } \\
\text { Squares }\end{array}$ & $\mathrm{df}$ & $\begin{array}{c}\text { Mean } \\
\text { Square }\end{array}$ & $\mathrm{F}$ & Sig \\
\hline \multirow{3}{*}{$\begin{array}{c}\text { Curriculum - } \\
\text { Related Proposed } \\
\text { Remedies } \\
\text { Administrative } \\
\text { Domain-Related } \\
\text { Proposed } \\
\text { Remedies } \\
\text { (at the levels of } \\
\text { Ministry of } \\
\text { Education and } \\
\text { Schools) } \\
\end{array}$} & Between Groups & 1.01 & 2 & 0.51 & \multirow[b]{3}{*}{1.83} & \multirow[b]{3}{*}{0.18} \\
\hline & Within Groups & 26.54 & 96 & 0.28 & & \\
\hline & Total & 27.55 & 98 & - & & \\
\hline \multirow{3}{*}{$\begin{array}{c}\text { Teachers-Related } \\
\text { Proposed } \\
\text { Remedies }\end{array}$} & Between Groups & 1.17 & 2 & 0.59 & \multirow{3}{*}{1.91} & \multirow{3}{*}{0.15} \\
\hline & Within Groups & 29.44 & 96 & 0.31 & & \\
\hline & Total & 30.61 & 98 & - & & \\
\hline \multirow{3}{*}{$\begin{array}{c}\text { Curriculum - } \\
\text { Related Proposed } \\
\text { Remedies }\end{array}$} & Between Groups & 1.13 & 2 & 0.57 & \multirow{3}{*}{1.76} & \multirow{3}{*}{0.21} \\
\hline & Within Groups & 30.97 & 96 & 0.32 & & \\
\hline & Total & 32.11 & 98 & & & \\
\hline \multirow{3}{*}{ Overall } & Between Groups & 0.88 & 2 & 0.44 & \multirow{3}{*}{1.44} & \multirow{3}{*}{0.30} \\
\hline & Within Groups & 29.38 & 96 & 0.31 & & \\
\hline & Total & 30.26 & 98 & & & \\
\hline
\end{tabular}

Furthermore, and at the level of the domains, results, as shown in the table (20) confirm that there were no statistically significant differences at $\alpha \leq 0.05$ among the perceptions of teachers related to 
any of the three domains (curriculum, administrative, and teacher related remedies That could be attributed to the variable of gender, where their $(\mathrm{F})$ values are respectively reached $(1.83,1.91$ and 1.76) which are not statistically significant at the level $(\alpha \leq 0.05)$.

Discussions for the results related to the research fourth question

It was reported that there were no significant statistical differences at $\alpha \leq 0.05$ in English language teacher's perceptions regarding the suggested solutions to overcome reading difficulties faced by $9^{\text {th }}$ grade students based on the variables of gender and years of experience.

Once again, the researchers could explain these results by the similarity existed in the educational environment in male and female schools and the difficulties faced by teachers in teaching reading skills in public schools, which in turn led to the absence of any convergence in their perceptions toward the solutions proposed to overcome reading difficulties faced by $9^{\text {th }}$ grade students based on the variable of gender and years of experience. The results of this study aren't in agreement with several findings of previous studies, which interpret the necessity of conducting such this study, where the origin of the differences could be related to the differences on the study's population and sometimes to its instruments.

\subsection{Recommendations}

Based on the findings of this study, the following recommendations could be suggested

1- Further research should be conducted to study the reading difficulties in English language from the perspective of other stakeholders such as; the students and their parents.

2- Curriculum designers are required to pay more attention to English Language curriculum, where it should be designed in such a way that may encourage learners to read various 
types of reading materials for specific purposes e.g. library resources and poem enjoyment.

3- Teachers are encouraged to adopt the learning strategies that provide the opportunity for reading assignments.

4- Enriching and reinforcing the English language curriculum with different types of reading that include group communication, narration, storytelling, self-questioning, activating background knowledge. 


\section{References}

Albdour, Waddah Mahmoud (2015) The Difficulties That Seventh Grade Students Face in Comprehensive Reading Skill for English Curricula. Journal of Education and Practice, v6 n27 p61-74 2015

Aljamal, Dina and Garaibeh, Sarra (2016) Communication Strategies for Teachers and their Students in an EFL Setting. International Journal of Bilingual \& Multilingual Teachers of English.4, No.1: 33-44.

AL-Khuli, M. (2000). Teaching English as Foreign Language. Riyad, International Journal of Linguistics Vol. 4, No. 3.

Bell, T. (2001). Extensive Reading: Speed and Comprehension. The Reading Matrix, 1 (1).

Carrell, P. (1987). Content and Formal Schemata in ESL Reading. TESOL Quarterly, 21:461-481.

Catts, M, and Hogan, I (2003). Cognitive process in early reading development: Accommodating individual differences into a model. HRD Products. Journal of Learning Disabilities, $36,151-164$.

Commeyrars, M. and Inyega, H. (2007). Relationships between oral reading rates for letters, words, and simple text in the development of reading achievement. Reading Research Quarterly .47. 2.

Duffy, G., Roehler, L., \&Herman, G. (1988). Modeling mental processes helps poor readers become strategic readers, Reading Teacher, 41, 762-767.

Erica S. Edwards, Kali Burke, James R. Booth, Chris Mc Norgan (2018). Dyslexia on a continuum: A complex network approach. Research Article as retrieved in July, the $18^{\text {th }}$, 2019 from

the: https://doi.org/10.1371/journal.pone.0208923 
Gay, G. (2011). Gutturally Responsive Teaching: Theory, Research, Practice. New York: Teachers College Press. Amsterdam Avenue, New York.

Hosp, A. and Reschly, D. (2003). Teaching and Learning Reading in the Language Classroom. Oxford: University Press.

Jeanne'S.'Chall (1983). Stages of Reading Development. New York: McGraw Hill. Journal of English Language Literature and Teaching, Vol () Issue () pp. 10-24

Karanja, W (2015). Effect of reading difficulties on academic performance among form three students in public secondary school, Kenya. Unpublished M.Ed. thesis.

Khankar, W. (2002). Identify the Most Important Problems of the English Language Curriculum as Perceived by Teachers in Al- Taif District. Umm Al-Qura University. College of Education, Mecca. Unpublished M.Ed., Thesis.

Maggi, W. (2004). An Investigation of Collaboration Among School Professionals in Serving Culturally and Linguistically Diverse Students with Exceptionalities. Bilingual Research Journal, 27(1).

Available [on-line]http://brj.asu.edu/content /vol27_no1/ documents / art 6 .pdf. As retrieved in / / 2019

Manamukubi, L (2013) Reading Difficulties in Grade Six Learners and Challenges Faced by Teachers in Teaching Reading: A case of Chadiza and Chipata district, Zambia. Unpublished Master thesis, The University of Zambia, Lusaka.

Manis, F.; Lindsey, K. and Bailey, C. (2004). Development of Reading in Grades K-2 in Spanish Speaking English Language Learners. Learning Disabilities Research and Practice.

Michael., S. W, T., \& Bonnie, B. Graves, (1999), Sensational, of Elementary Reading, Allyn and Bacon. Subsequent edition. USA. 
Ministry of Education (2011). Action Pack 9: Teacher's Book. Jordan,

York Press.

Mule, M (2014). Reading difficulties in grade six learners and challenges faced by teachers in teaching reading: A case of Chadiza and Chipata district, Zambia. Unpublished M.Ed. thesis.

Novi, S (2015). Reading difficulties in English as a foreign language. Unpublished PhD. Dissertation. University of Novi Sad, Faculty of Philosophy.

Nunan, D. (2003). Practical English Language Teaching. Boston: McGraw Hill. Journal of Social Sciences, Vol.4 No.3.

Nurjanah, R. (2018). The analysis on student's difficulties in doing reading comprehension final test. Journal language literature and teaching. Vol.2, No2, pp253-264.

Ojanen, E. (2007). Sewero La -mau-u-A Phonetic Approach to Literacy Teaching in Zambia. Unpublished Master degree thesis of Psychology, University of Jyvaskyla.

Paris, S. (2005). Reinterpreting the Development of Reading Skills, Reading Research Quarterly, 40(.2): 184-202.

Peyrard-Janvid, M., Anthoni, H., Onkamo, P., Lahermo, P., Zucchelli, M., Kaminen, N., Hannula-Jouppi, K., NopolaHemmi, J., Voutilainen, A., Lyytinen, $\mathrm{H} \&$ Kere, J. (2004). Fine Mapping of the 2p11 Dyslexic Locus and Exclusion of TACRI as a Candidate Gene.114: 510-516.

Pigada, M. and Schmitt, N. (2006). Vocabulary Acquisition for Extensive Reading. A case study Reading in a foreign Language. Reading in a Foreign Language Volume 18, No. 1, pp1-28.

Roe, M, F. (1992) Reading strategy instruction complexities and possibilities in middle school, Journal of Reading, 36, (3): 190-196. 
Rudd Ell, R.B, (1992), A whole Language and Literature Perspective: Creating a meaning to making instructional environment. Language Arts, 69,612- 620.

Smith, F. (2004). Understanding Reading. A Psycholinguistic Analysis of Reading and Learning to Read. ( $6^{\text {th }}$ Edition). Lawrence Erlbaum Associates, Publishers Mahwah, New Jersey London.

Snow, C.E., Burns, M.S., \& Griffin, P. (eds.) (1998). Preventing reading difficulties in young children. Washington, DC: National Academy Press, pp 432.

Yassen, A. (2013). The reading difficulties in English and how to deal with them as perceived by teachers and students in Nablus District. Unpublished M.Ed. thesis. 
